\title{
Środek karny z art. 39 pkt 2b k.k. a prawo ofiary i sprawcy do samostanowienia
}

\begin{abstract}
The penal measure of a prohibition on being in certain communities and locations, on contacting certain individuals or on approaching certain individuals or on leaving a specific place of residence without the court's consent, evidently restricts the liberty of a person sentenced. The said restriction most of all serves to implement the preventative function of penal law, particularly the protection of the victim against the repeat victimisation. At the same time, however, implementing this measure interferes with the victim's life. Insofar as the restriction of the perpetrator's liberty is in this case fully justified, ignoring the opinion of the victim in decision-making process pertaining to implementation of the discussed legal measure does not meet the constitutional criterion of proportionality.
\end{abstract}

Keywords: victim, perpetrator, a prohibition on being in certain communities and locations, a prohibition on contacting certain individuals, a prohibition on approaching certain individuals, a prohibition on leaving a specific place of residence without the court's consent

Prawo karne z pewnością nie jest tą dziedziną prawa, która szczególnie kojarzyłaby się z autonomią i wolnością. Sprawca przestępstwa jest postacią centralną Kodeksu karnego, a - jako oskarżony - także Kodeksu postępowania karnego. Jednak ta kluczowa rola nie wiąże się z władzą, wręcz przeciwnie - sprawca/oskarżony w sposób dobitny tej władzy podlega, a jego prawa i wolności są nieprzypadkowo narażone na uszczuplenie. Także pokrzywdzony, choć nie podlega osądowi i odpowiedzialności karnej, to zasadniczo w swych rękach żadnej władzy nie dzierży ${ }^{1}$. Rola ofiary przestępstwa $\mathrm{w}$ procesie wymiaru odpowiedzialności karnej była od wieków świadomie marginalizowana². Marian Filar pisze bez ogródek:

${ }^{1}$ Zakres „władzy” pokrzywdzonego zależny jest m.in. od trybu ścigania danego typu czynu zabronionego.

2 Por. L. Falandysz: Pokrzywdzony w prawie karnym i wiktymologii. Warszawa 1980, s. 3; C. KulesZa: Rola pokrzywdzonego $w$ procesie karnym $w$ świetle ustawodawstwa i praktyki 
„głównym celem wymiaru sprawiedliwości jest wymiar sprawiedliwości, a nie »dopieszczanie« pokrzywdzonego”, a dalej: „bycie pokrzywdzonym przestępstwem niestety musi »boleć«, także i w trakcie procesu karnego, którego celem jest realizacja aktu wymiaru sprawiedliwości”3.

Równocześnie jednak zaobserwować można, że druga połowa XX w. przyniosła rozwój systemu ochrony indywidualnych praw człowieka ${ }^{4}$, szczególne zainteresowanie prawami osób pokrzywdzonych przestępstwem $^{5}$, a także poszukiwania alternatywy dla państwowego ius punien$d i^{6}$. Postulaty wiktymologów i zwolenników sprawiedliwości naprawczej zapoczątkowały zmiany $\mathrm{w}$ prawie karnym sensu largo, zmierzające do upodmiotowienia pokrzywdzonego ${ }^{7}$. Obecnie, jak pisze Igor Nestoruk, „konieczność uwzględnienia interesów pokrzywdzonego należy do zasadniczych - wartych szczególnego podkreślenia - standardów nowej polskiej procedury karnej. Zmiany w prawie polskim odpowiadaja $\mathrm{w}$ tym przedmiocie tendencji rozwojowej procedury karnej na świecie, która zmierza do zabezpieczenia interesów pokrzywdzonego $\mathrm{w}$ procesie karnym. Wiąże się to z kolei z zasadniczą zmianą filozofii prawa karnego i polityki karnej"». Uzasadnione jest więc poszukiwanie przestrzeni dla poszanowania woli stron również w obszarze materialnego prawa karnego.

Prawo jednostki do samostanowienia wpisuje się w przyrodzoną godność człowieka oraz wypływające z niej prawo do wolności i prywatności ${ }^{9}$. Prawa te doznają oczywistych ograniczeń, m.in. w ramach prawa karnego. Konstytucyjną podstawę tych ograniczeń stanowi przede wszystkim art. $31 \S 3$ Konstytucji RP normujący zasadę proporcjonalności ${ }^{10}$. W myśl tego przepisu ograniczenia w zakresie korzystania z konstytucyjnych

krajów zachodnich. Białystok 1995, s. 9; W. ZALEwsKi: Sprawiedliwość naprawcza. Początek ewolucji polskiego prawa karnego?. Gdańsk 2006, s. 7.

${ }^{3}$ M. FILAR: Pokrzywdzony (ofiara przestępstwa) $w$ polskim prawie karnym materialnym. CPKiNP 2002, nr 2, s. 28.

${ }^{4}$ Por. np. W. Osiatyński: Filozofia i historia praw człowieka. W: Prawa człowieka a policja. Problemy teorii i praktyki. Red. A. RzePLIŃsKI. Legionowo 1994.

${ }^{5}$ Por. np. L. Falandysz: Pokrzywdzony w prawie karnym..., s. 3.

${ }^{6}$ Por. np. W. Zalewski: Sprawiedliwość..., s. 7.

${ }^{7}$ E. Bı̈ŃкоwsкA, D. WóJciK: Pokrzywdzony i sprawca przestępstwa. W: Zagadnienia ogólne. System Prawa Karnego. T. 1. Red. A. MareK. Warszawa 2010, s. 326.

${ }^{8}$ I.B. NestoruK: Wnioskowy tryb ścigania przestępstw $w$ polskim i niemieckim prawie karnym. RPEiS 2001, z. 4, s. 89.

${ }^{9}$ Por. P. Sarnecki. W: Konstytucja Rzeczypospolitej Polskiej. Komentarz. T. 3. Red. L. GarlickI. Warszawa 2003, (Artykuł 47), s. 2-4; L. BoseK: Komentarz do art. 30 Konstytucji RP. W: Konstytucja RP. T. I. Komentarz do art. 1-86. Red. M. SAfJAn, L. BoseK. Warszawa 2016, Legalis; M. Szydıo: Komentarz do art. 31 Konstytucji RP. W: Konstytucja RP. T. I...; M. WILD: Komentarz do art. 47 Konstytucji RP. W: Konstytucja RP. T. I...

${ }^{10}$ Por. M. SzYdŁo: Komentarz do art. 31 Konstytucji RP. W: Konstytucja RP. T. I... 
wolności i praw mogą być ustanawiane tylko w ustawie i tylko wtedy, gdy są konieczne $\mathrm{w}$ demokratycznym państwie dla jego bezpieczeństwa lub porządku publicznego, bądź dla ochrony środowiska, zdrowia i moralności publicznej, albo wolności i praw innych osób. Oznacza to, że ograniczenie prawa lub wolności może nastąpić tylko wtedy, gdy przemawia za tym inna norma, zasada lub wartość konstytucyjna, a stopień tego ograniczenia musi pozostać $\mathrm{w}$ odpowiedniej proporcji do rangi interesu, któremu ograniczenie to ma służyć ${ }^{11}$. Zaryzykować można wiec twierdzenie, że rozmaite instytucje materialnego prawa karnego tylko wówczas ograniczać mogą swobodę jednostki (sprawcy lub pokrzywdzonego), gdy służy to realizacji ważnych społecznie funkcji prawa karnego przewyższających swą wartością to dobro indywidualne.

Zasygnalizowany wyżej problem zdaje się mieć wielką wagę i zasługuje na wszechstronną analizę. W ramach niniejszego artykułu chcę zbadać jedynie wycinek tego zagadnienia. Przedmiotem badań czynię środek karny z art. 39 pkt 2b k.k., który wprowadzony został do Kodeksu karnego w dość precyzyjnie określonym celu. Projektodawca założył, że zakaz przebywania w określonych środowiskach lub miejscach, kontaktowania się z określonymi osobami, zbliżania się do określonych osób lub opuszczania określonego miejsca pobytu bez zgody sądu zapewnić ma „ochronę przed kontynuowaniem działalności przestępczej przez osoby, które z pobudek seksualnych dopuszczają się groźnych przestępstw"12. Nowelizacja z 29 lipca 2005 r. poszerzyła zakres zastosowania tego przepisu na sytuacje związane z szeroko pojętą przemocą ${ }^{13}$. Zatem główną choć nie jedyną - funkcją omawianego środka karnego jest ochrona prewencyjnego interesu pokrzywdzonego. Taka wstępna teza uzasadnia postawienie pytania o to, na ile ten pokrzywdzony może i powinien być włączony $\mathrm{w}$ proces decyzyjny związany $\mathrm{z}$ orzekaniem środka $\mathrm{z}$ art. 39 pkt $2 \mathrm{~b}$ k.k. Równocześnie zaś nie ulega wątpliwości, że tego typu zakazy ograniczają swobodę skazanego, a to każe postawić pytanie - czy zasadnie?.

Środek karny wymieniony w art. 39 pkt 2 b wyraża się w kilku dość różnych zakazach, które jednak łączy to, że ograniczają wolność skaza-

11 D. Fleszer: Godność i prywatność osoby w świetle Konstytucji Rzeczypospolitej Polskiej. „Roczniki Administracji i Prawa” nr XV(1), s. 28.

12 Uzasadnienie projektu ustawy o zmianie ustawy Kodeks karny i Kodeks karny wykonawczy z 5.03.2004 r., druk sejmowy nr 2693. Projekt nie zawierał jeszcze omawianych środków, pojawiły się $\mathrm{w}$ toku prac legislacyjnych, ale zmierzają w tym samym kierunku (por. M. MelezINI: Środki karne jako instrument polityki kryminalnej. Białystok 2013, s. 118).

13 Art. 15 pkt 1 ustawy z dnia 29 lipca 2005 r. o przeciwdziałaniu przemocy w rodzinie, Dz.U. 2005, nr 180, poz. 1493. 
nego ${ }^{14}$. Można uznać, że art. 39 pkt 2 b przewiduje cztery różne odmiany tego środka, które sąd może orzec oddzielnie lub łącznie:

- zakaz przebywania w określonych środowiskach lub miejscach,

- zakaz kontaktowania się z określonymi osobami,

- zakaz zbliżania się do określonych osób,

- zakaz opuszczania określonego miejsca pobytu bez zgody sądu' ${ }^{15}$.

Zakazy z art. 39 pkt 2 b są scharakteryzowane w art. 41a k.k. łącznie z innym jeszcze środkiem karnym ograniczającym swobodę przemieszczania się skazanego, a mianowicie z nakazem okresowego opuszczenia lokalu zajmowanego wspólnie z pokrzywdzonym z art. 39 pkt 2e. Ten środek nie stanowi jednak osi niniejszych rozważań.

Lektura piśmiennictwa dotyczącego omawianego środka nie pozostawia wątpliwości - jego pierwszorzędną funkcją jest prewencja indywidualna, zwłaszcza negatywna ${ }^{16}$. Wskazuje na to zarówno cytowane już uzasadnienie ustawy nowelizacyjnej, jak i przesłanki stosowania przedmiotowych zakazów. Istota poszczególnych zakazów pozwala założyć, że zwłaszcza w przypadku zakazu kontaktowania się i zbliżania do określonych osób - istotnym celem stosowania tego środka jest ochrona osób pokrzywdzonych przez danego sprawcę przed kolejną wiktymizacją ${ }^{17}$.

14 Tak A. SAKowicz: Zakaz przebywania $w$ określonych środowiskach lub miejscach, kontaktowania się z określonymi osobami, zbliżania się do określonych osób lub opuszczania określonego miejsca pobytu bez zgody sadu. W: Kary i inne środki reakcji prawnokarnej. System Prawa Karnego. T. 6. Red. M. MelezINI. Warszawa 2016, s. 626, a także - na gruncie Konstytucji RP - J. KośLA: Zakaz przebywania w określonych środowiskach lub miejscach, kontaktowania się z określonymi osobami, zbliżania się do określonych osób lub opuszczania określonego miejsca pobytu bez zgody sądu. W: Środki karne po nowelizacji w 2015 roku. Red. R.A. STEFAŃSKI. Warszawa 2016, s. 147-148.

15 Tak też np. M. MelezinI, A. SAKowicz: Zakaz przebywania w określonych środowiskach lub miejscach, kontaktowania się z określonymi osobami, zbliżania się do określonych osób lub opuszczania określonego miejsca pobytu bez zgody sq̨u. CPKiNP 2008, nr 2, s. 198; J. KośLA: Zakaz przebywania w określonych środowiskach lub miejscach, kontaktowania się z określonymi osobami, zbliżania się do określonych osób lub opuszczania określonego miejsca pobytu bez zgody sqdu. W: Środki karne..., s. 147; M. KuLIK: Zakaz przebywania w określonych środowiskach lub miejscach, kontaktowania się z określonymi osobami, zbliżania się do określonych osób lub opuszczania określonego miejsca pobytu bez zgody sadu. W: Środki karne, przepadek $i$ środki kompensacyjne w znowelizowanym Kodeksie karnym. Red. P. DANILUK. Warszawa 2017, s. 108.

${ }_{16}$ Por. zwłaszcza M. Kulik: Zakaz przebywania w określonych środowiskach lub miejscach, kontaktowania się z określonymi osobami, zbliżania się do określonych osób lub opuszczania określonego miejsca pobytu bez zgody sądu. W: Środki karne..., s. 107; także J. KośLA: Zakaz przebywania $w$ określonych środowiskach lub miejscach, kontaktowania się z określonymi osobami, zbliżania się do określonych osób lub opuszczania określonego miejsca pobytu bez zgody sadu. W: Środki karne..., s. 149.

${ }_{17}$ Tak też M. Kulıк: Zakaz przebywania $w$ określonych środowiskach lub miejscach, kontaktowania się z określonymi osobami, zbliżania się do określonych osób lub opuszczania określonego miejsca pobytu bez zgody sq̨du. W: Środki karne..., s. 107-108. 
W ramach funkcji prewencyjnej przypisuje się zakazom z art. 39 pkt 2 b k.k. także pozytywne oddziaływanie ogólno- i szczególnoprewencyjne $^{18}$. Omawiany środek może wspierać skazanego w korekcie niepożądanych postaw. Podkreślić jednak należy za Sylwią Spurek, że intencją ustawodawcy nie było odizolowanie sprawcy od zgubnego wpływu otoczenia, a raczej ochrona tego „otoczenia”19. Równocześnie zaś komentowany środek promuje ważne normy społeczne związane z traktowaniem małoletnich czy członków rodziny.

Analizowany środek, jako że wyraźnie ogranicza wolność skazanego, jest też środkiem dolegliwym, pełniącym funkcję represyjną. Jednak w literaturze podkreśla się, że cel sprawiedliwościowy ma w tym przypadku drugorzędne znaczenie ${ }^{20}$.

Przedstawione rozważania potwierdzają dobitnie słuszność przyjętej tezy - główną rolą, jaką odegrać powinny zakazy z art. 39 pkt 2b k.k., jest zabezpieczenie interesów prewencyjnych indywidualnej ofiary oraz społeczeństwa, zwłaszcza grup potencjalnie narażonych na pokrzywdzenie ponownym popełnieniem przestępstwa przez skazanego. By poddać tę regulację testowi proporcjonalności, ustalić należy, ochronie jakich dóbr służy analizowany środek.

Warto za Markiem Kulikiem powtórzyć, że w myśl art. 41a „omawiany środek można orzec: 1) zawsze w razie popełnienia umyślnego przestępstwa z użyciem przemocy, w tym zwłaszcza przemocy wobec osoby najbliższej; 2) za przestępstwa przeciwko wolności seksualnej lub obyczajności na szkodę małoletniego (w tym wypadku przesłanką dodatkową jest małoletniość pokrzywdzonego w czasie czynu); 3) zawsze w razie popełnienia przestępstwa przeciwko wolności, z wyłączeniem przestępstw

18 Por. A. SAKowicz: Zakaz przebywania w określonych środowiskach..., s. 627; J. KośLA: Zakaz przebywania $w$ określonych środowiskach lub miejscach, kontaktowania się z określonymi osobami, zbliżania się do określonych osób lub opuszczania określonego miejsca pobytu bez zgody sqdu. W: Środki karne......, s. 149.; M. KuLIK: Zakaz przebywania w określonych środowiskach lub miejscach, kontaktowania się z określonymi osobami, zbliżania się do określonych osób lub opuszczania określonego miejsca pobytu bez zgody sq̨du. W: Środki karne..., s. 107.

19 S. SpUReк: Ustawa o przeciwdziataniu przemocy $w$ rodzinie. Praktyczny komentarz. Warszawa 2011, s. 212-213. Tak też A. KomAdowsKa: Stosowanie kar i środków karnych wobec sprawców przemocy domowej jako przejaw realizacji funkcji prewencyjnej kary. W: M. Kopeć: Prawnokarna ochrona pokrzywdzonych przemoca domowa. Lublin 2017, s. 119.

${ }^{20}$ Por. zwłaszcza J. KośLA: Zakaz przebywania w określonych środowiskach lub miejscach, kontaktowania się z określonymi osobami, zbliżania się do określonych osób lub opuszczania określonego miejsca pobytu bez zgody sadu. W: Środki karne..., s. 149; M. KuLIK: Zakaz przebywania $w$ określonych środowiskach lub miejscach, kontaktowania się z określonymi osobami, zbliżania się do określonych osób lub opuszczania określonego miejsca pobytu bez zgody sqdu. W: Środki karne..., s. 107. 
przeciwko wolności seksualnej popełnionych na szkodę małoletniego" ${ }^{21}$. Przedstawione wyliczenie przesłanek nie wskazuje, kiedy sąd orzeka, a kiedy tylko może orzec wskazany środek karny ani czy może nałożyć wybrany zakaz dożywotnio; kwestie te nie są jednak kluczowe dla określenia dóbr prawnych, którym potencjalnie zagraża sprawca. Wskazane przesłanki niezbicie dowodzą, że zakaz służyć ma ochronie wolności w ogólności, a w szczególności - wolności seksualnej i obyczajności małoletnich. Nieco trudniejsza do interpretacji jest kwestia umyślnych przestępstw z użyciem przemocy.

Pojęcie przemocy pojawia się wprost jako znamię niektórych typów czynów zabronionych (np. art. 191, 197, 203, 207, 232, 242 §2, art. 250 czy 280 k.k.), ale w doktrynie wskazuje się także szersze rozumienie zwrotu „przestępstwo z użyciem przemocy”, obejmujące każdy czyn popełniony faktycznie z użyciem przemocy ${ }^{22}$. Andrzej Sakowicz racjonalnie broni stanowiska, że w art. 41a k.k. chodzi wyłącznie o przestępstwa, które mają przemoc wśród znamion ${ }^{23}$, jednak wydaje się, że współcześnie to stanowisko jest w mniejszości. Jeśli jednak przyjąć tę szerszą interpretację, to problemem pozostaje rozumienie samej przemocy. Kodeks karny nie zawiera definicji tego pojęcia. W doktrynie utrwalił się pogląd, że przemoc w prawie karnym to „oddziaływanie środkami fizycznymi nakierowane na przełamanie lub uniemożliwienie oporu ofiary i mające na celu niedopuszczenie do swobodnego powstania i wykonania aktu woli ofiary albo nastawienie jej procesów motywacyjnych w kierunku zachowania pożądanego przez sprawcę" ${ }^{24}$, a więc wyłącznie przemoc fizyczna. Jacek Kośla sugeruje ${ }^{25}$

${ }^{21}$ Ibidem, s. 107-108.

22 Tak np. R.A. STEFAŃsKI: Środek karny $w$ postaci obowiazku powstrzymania się od przebywania w określonych środowiskach lub miejscach, zakazu kontaktowania się z określonymi osobami lub zakazu opuszczania określonego miejsca pobytu bez zgody sqdu. PS 2006, nr 6, s. 69; N. KŁąCZYŃsKa: Komentarz do art. 41a. W: Kodeks karny. Część ogólna. Komentarz. Red. J. GıEZEK. Warszawa 2012, s. 333; J. KośLA: Zakaz przebywania w określonych środowiskach lub miejscach, kontaktowania się z określonymi osobami, zbliżania się do określonych osób lub opuszczania określonego miejsca pobytu bez zgody sądu. W: Środki karne..., s. 153; M. Kulik: Zakaz przebywania w określonych środowiskach lub miejscach, kontaktowania się z określonymi osobami, zbliżania się do określonych osób lub opuszczania określonego miejsca pobytu bez zgody sadu. W: Środki karne..., s. 107.

23 A. SAKowicz: Zakaz przebywania w określonych środowiskach..., s. 637.

${ }^{24}$ O. SitARz: Ustawowe znamiona czynu zabronionego. W: Prawo karne. Część ogólna, szczególna $i$ wojskowa. Red. T. DuKIET-NaGórsKa. Warszawa 2018, s. 112-113; por. też M. KuLIK: Zakaz przebywania $w$ określonych środowiskach lub miejscach, kontaktowania się z określonymi osobami, zbliżania się do określonych osób lub opuszczania określonego miejsca pobytu bez zgody sadu. W: Środki karne..., s. 107-108.

25 J. KoślA: Zakaz przebywania $w$ określonych środowiskach lub miejscach, kontaktowania się z określonymi osobami, zbliżania się do określonych osób lub opuszczania określonego miejsca pobytu bez zgody sqdu. W: Środki karne..., s. 153-154. 
sięgnięcie do definicji przemocy w rodzinie z art. 2 pkt 2 ustawy o przeciwdziałaniu przemocy w rodzinie ${ }^{26}$. Kierunek ten jest o tyle zrozumiały, że wprowadzenie środka z art. 39 pkt 2b do Kodeksu karnego ma po części genetyczny związek ze wskazaną ustawą ${ }^{27}$. Definicja ta jednak jest przedmiotowo daleko szersza od rozumienia „przemocy” przyjętego na gruncie k.k., co czyni tę interpretację niewłaściwą, bo prowadzącą do terminologicznego rozbicia Kodeksu karnego.

Uznanie, że przestępstwa z użyciem przemocy, o których mowa $\mathrm{w}$ art. 42a k.k., to wyłącznie przestępstwa popełnione z faktycznym użyciem przemocy fizycznej, pozwala na ustalenie, jakie dobra mogą być przez te przestępstwa zagrożone. Sprawca przemocy oddziałuje na sferę wolicjonalną człowieka (choćby pośrednio, przez rzecz), a zatem godzi w jego wolność. Natomiast przemoc wobec osoby oznacza zwykle jakąśs formę naruszenia jej nietykalności cielesnej, może zagrażać zdrowiu i życiu ofiary. Dodać należy, że ustawodawca wyróżnił w art. 42a k.k. przemoc wobec osoby najbliższej, co każe uznać, że czyny objęte zakresem przesłanek zastosowania omawianego środka karnego to także wybrane przestępstwa przeciwko rodzinie i opiece. Katalog dóbr, dla ochrony których powołano środek karny z art. 39 pkt 2b k.k., obejmuje zatem co najmniej wolność, wolność seksualną i obyczajność małoletnich, nietykalność cielesną, zdrowie, a nawet życie oraz prawidłowe funkcjonowanie rodziny.

Powtórzmy, że zgodnie z art. 31 ust. 3 Konstytucji RP „ograniczenia w zakresie korzystania z konstytucyjnych wolności i praw mogą być ustanawiane tylko w ustawie i tylko wtedy, gdy są konieczne w demokratycznym państwie dla jego bezpieczeństwa lub porządku publicznego, bądź dla ochrony środowiska, zdrowia i moralności publicznej, albo wolności i praw innych osób. Ograniczenia te nie mogą naruszać istoty wolności i praw". Wymienione w poprzednim akapicie dobra chronione poprzez zastosowanie komentowanego środka z pewnością mieszczą się w przywołanym katalogu, przy tym należą do dóbr najcenniejszych ${ }^{28}$. Zasada

${ }^{26}$ Ustawa z dnia 29 lipca 2005 r. o przeciwdziałaniu przemocy w rodzinie, Dz.U. 2005 nr 180, poz. 1493. Art. 2 pkt 2 przemocy w rodzinie - należy przez to rozumieć jednorazowe albo powtarzające się umyślne działanie lub zaniechanie naruszające prawa lub dobra osobiste osób wymienionych w pkt 1, w szczególności narażające te osoby na niebezpieczeństwo utraty życia, zdrowia, naruszające ich godność, nietykalność cielesną, wolność, w tym seksualną, powodujące szkody na ich zdrowiu fizycznym lub psychicznym, a także wywołujące cierpienia i krzywdy moralne u osób dotkniętych przemocą.

${ }^{27}$ Por. np. J. KośLA: Zakaz przebywania w określonych środowiskach lub miejscach, kontaktowania się z określonymi osobami, zbliżania się do określonych osób lub opuszczania określonego miejsca pobytu bez zgody sq̨du. W: Środki karne..., s. 145-146.

${ }^{28}$ W szczególności uwaga ta dotyczy wolności człowieka, por. np. M. SzYDŁO: Komentarz do art. 31 Konstytucji RP. W: Konstytucja RP. T. I... 
proporcjonalności wywodzona z art. 31 ust. 3 Konstytucji nakazuje zbadanie skuteczności, konieczności i proporcjonalności sensu stricto analizowanego rozwiązania ${ }^{29}$. Jeżeli kontakt skazanego z osobami już wcześniej przez niego pokrzywdzonymi lub takimi, które potencjalnie mógłby skrzywdzić, istotnie zagraża takim dobrom prawnym jak wolność, wolność seksualna czy zdrowie, to bez wątpienia wskazane jest, by ten kontakt utrudnić. Na konieczność taką wskazuje nie tylko polski ustawodawca, ale też regulacje międzynarodowe, na czele z konwencją Rady Europy o zapobieganiu i zwalczaniu przemocy wobec kobiet i przemocy domowej ${ }^{30}$. Jeśli zaś wolność (i inne dobra) ofiary ma być skutecznie ${ }^{31}$ chroniona kosztem pewnego ograniczenia wolności sprawcy, to nie powinno budzić wątpliwości, że rozwiązanie takie jest proporcjonalne.

W świetle przedstawionych wyżej rozważań uznać należy, że ograniczenie wolności sprawcy przestępstwa poprzez zastosowanie jednego z zakazów jest w pełni konstytucyjne. Czy jednak ograniczenie to powinno być niezależne od woli podsądnego? Pierwszoplanowa rola prewencji negatywnej sprawia, że uwzględnianie woli sprawcy w toku podejmowania decyzji o zastosowaniu któregoś z zakazów z art. 39 pkt 2b k.k. wydaje się absolutnie wykluczone. Oczekiwanie, że skazany zaakceptuje omówione ograniczenia, najczęściej będzie całkowicie bezpodstawne. Uzależnianie bezpieczeństwa pokrzywdzonego od woli sprawcy byłoby co najmniej lekkomyślne.

Wykazane wyraźne powiązanie analizowanego środka z prewencyjnym interesem zindywidualizowanej ofiary i jej bliskich każe zastanowić się nad rolą pokrzywdzonego $\mathrm{w}$ procesie decyzyjnym dotyczącym środka karnego z art. 39 pkt 2b k.k. Myśl, by w ramach przesłanek fakultatywnego stosowania komentowanych zakazów uwzględniać wolę ofiary, pojawiła się już w polskiej literaturze za sprawą Wojciecha Zalewskiego ${ }^{32}$, a następnie rozwinięta została m.in. przez Elżbietę Hryniewicz-Lach, w oparciu o dyskusję toczącą się na forum międzynarodowym ${ }^{33}$. Potrzeba silniejszego

29 Ibidem.

30 Art. 52, 53, a zwłaszcza art. 56 konwencji Rady Europy o zapobieganiu i zwalczaniu przemocy wobec kobiet i przemocy domowej z dnia 11 maja 2011 r., Dz.U. 2015, poz. 961. Por. też S. SPuREK: Izolacja sprawcy od ofiary. Instrumenty przeciwdziałania przemocy $w$ rodzinie. Warszawa 2013, s. 47-92.

31 Skuteczność tę podnosi poddanie skazanego dozorowi elektronicznemu zgodnie $\mathrm{z}$ art. $41 \mathrm{a} \S 1$ i 2 k.k., por. A. MichalsKA-WARIAs: Prawnokarne środki przeciwdziałania przemocy seksualnej między małżonkami w teorii i praktyce. W: M. Kopeć: Prawnokarna ochrona pokrzywdzonych przemoca domowa. Lublin 2017, s. 53.

32 W. ZALEWSKI: Komentarz do art. $41 a$ k.k. W: Kodeks karny. Część ogólna. T. II: Komentarz do art. 32-116. Red. M. KróliKowsKI, R. ZAwŁOCKI. Warszawa 2011, s. 75.

33 E. HRYNIEWICZ-LACH: Ofiara $w$ polskim prawie karnym. Interesy ofiary przestępstwa i karno-materialne instrumenty stużace ich zabezpieczeniu. Warszawa 2017, s. 334-337 i przywołana tam literatura. 
uwzględniania zdania pokrzywdzonego w sytuacji stosowania omawianego środka widoczna jest też wśród sędziów, którzy orzekając środek karny z art. 39 pkt 2b k.k., niejednokrotnie starają się doprecyzować jego zakres bardziej szczegółowo niż czyni to ustawodawca. Ustawa w art. 41a $\S 4$ zastrzega jedynie, że „orzekając zakaz zbliżania się do określonych osób, sąd wskazuje odległość od osób chronionych, którą skazany obowiązany jest zachować”, co należy ocenić jako regulację ważną z praktycznego punktu widzenia ${ }^{34}$, ale niewystarczającą. Sędziowie, wychodząc naprzeciw oczekiwaniom pokrzywdzonych, niejednokrotnie zaznaczają w wyrokach skazujących, że zakaz zbliżania się nie dotyczy np. innych postępowań sądowych, które toczą się między skazanym a pokrzywdzonym, lub spotkań koniecznych dla realizacji wyroku sądu rodzinnego w zakresie kontaktów skazanego z dzieckiem, względnie innych spotkań podejmowanych za zgodą lub nawet z inicjatywy pokrzywdzonego ${ }^{35}$. Zakaz kontaktów może być więc naruszany nie tylko z inicjatywy skazanego, ale także pokrzywdzonego, co naraża skazanego na negatywne konsekwencje prawne i krępuje swobodę osoby pokrzywdzonej. Rację ma więc E. Hryniewicz-Lach, gdy zwraca uwagę na mniejszą efektywność środków ochronnych stosowanych wbrew woli ofiary, której z założenia mają służyć ${ }^{36}$.

Przytoczone wyżej obserwacje pozwalają na sformułowanie wniosku, że część zakazów ujętych w art. 39 pkt 2b k.k. ogranicza nie tylko wolność skazanego, ale także swobodę ofiary poprzez ingerencję w jej życie osobiste. Choć takie ograniczenie nie jest celem stosowania środka, to jednak wkomponowane jest w jego istotę. Wypada się zastanowić, czy takie ograniczenie jest zgodne z zasadą proporcjonalności. Ograniczenie wolności człowieka dla jego własnego bezpieczeństwa jest przejawem paternalizmu władzy i stosowane jest tylko w skrajnych przypadkach. Przykładem może być przewidziane ustawą o ochronie zdrowia psychicznego stosowanie przymusu bezpośredniego wobec osoby z zaburzeniami psychicznymi, która zagraża swojemu życiu ${ }^{37}$. Czy ofiara przemocy domo-

34 Tak S. SPUREK: Ustawa..., s. 250.

35 Zgodnie z relacją SSO Jagny Rumińskiej sędziom zdarza się uzupełniać treść orzeczonego środka zakazu zbliżania się do określonych osób przykładowo zwrotem „bez zgody pokrzywdzonego” lub „za wyjątkiem kontaktów z dzieckiem i postępowań sądowych” (J. Rumińska, Sędzia Sądu Okręgowego w Katowicach, Wydział VI Karny Odwoławczy, głos w dyskusji na zebraniu Katedry Prawa Karnego i Kryminologii WPiA UŚ w Katowicach, 17.12.2018 r.).

${ }^{36}$ E. Hryniewicz-LaCH: Ofiara $w$ polskim prawie karnym..., s. 334-337. Por. szerzej A. JAWORSKA-WIELOCH: O potrzebie zachowania spójności wokót nakazu opuszczenia lokalu zajmowanego wspólnie z pokrzywdzonym. W: Wspótczesne przeksztatcenia sankcji karnych - zagadnienia teorii, wyktadni i praktyki stosowania. Red. P. GóRALsKI, A. MuszYŃsKa. Warszawa 2018, s. 241-257.

37 Ustawa z dnia 19 sierpnia 1994 r. o ochronie zdrowia psychicznego, t.j. Dz.U. 2018, poz. 1878 . 
wej jest z założenia tak dalece niesamodzielna, że nie może zdecydować o tym, czy chce - z różnych przyczyn - podtrzymywać kontakt ze sprawcą przemocy? Choć może tak się zdarzyćc ${ }^{38}$, nie wolno zakładać, że dotyczyć to będzie każdego przypadku. Ponadto nawet jeśli sąd uzna, że dla dobra ofiary zakaz kontaktowania lub zbliżania się jest konieczny nawet wbrew jej woli, to - z zasygnalizowanych już powodów - nie będzie on skuteczny. Wobec tego z przykrością zauważyć trzeba, że ograniczenie wolności pokrzywdzonego przestępstwem wynikające z zastosowania niektórych form zakazu z art. 39 pkt $2 \mathrm{~b}$ nie zdaje testu proporcjonalności. Pod tym względem można by więc kwestionować konstytucyjność tej regulacji.

Czy wobec powyższych obserwacji postulować można, by środek karny z art. 39 pkt 2 b orzekany był wyłącznie na wniosek lub za zgodą pokrzywdzonego? Cytowana przez Elżbietę Hryniewicz-Lach rzecznik generalna Unii Europejskiej Juliane Kokott uznaje, że przed orzeczeniem tego typu środków sąd powinien wysłuchać opinii ofiary, ale - aby nie wywierać na pokrzywdzonym presji i nie obarczać go odpowiedzialnością - sąd nie może być tą opinią związany ${ }^{39}$. Jeśli więc rzecznik generalna ma rację, to orzekanie środka karnego z art. 39 pkt $2 \mathrm{~b}$ za zgoda pokrzywdzonego nie byłoby wskazane. Sięgnięcie po takie rozwiązanie pozostawiałoby ostateczną decyzję $\mathrm{w}$ przedmiocie zastosowania środka w rękach ofiary przemocy, to na nią spadałby więc psychiczny ciężar ograniczeń dotykających skazanego. Równie obciążające dla ofiary mogłoby być stosowanie omawianych zakazów wyłącznie na wniosek pokrzywdzonego. Wprawdzie sąd mógłby takiego wniosku nie uwzględniać, więc to nie do pokrzywdzonego należałoby ostatnie słowo, ale przy takim rozwiązaniu to do ofiary należałaby inicjatywa zastosowania środka karnego. Pewną niechęć ofiar do brania odpowiedzialności za sankcje nakładane na sprawcę potwierdzają także badania ankietowe prowadzone wśród ofiar przemocy.

Dodatkowo trzeba mieć na uwadze fakt, że nie wszystkie zakazy ujęte $\mathrm{w}$ art. 39 pkt $2 \mathrm{~b}$ k.k. skoncentrowane są na interesie prewencyjnym zindywidualizowanej ofiary. Część z nich (zakaz przebywania w określonych środowiskach lub miejscach i zakaz opuszczania określonego miejsca pobytu) ma służyć także ochronie społeczeństwa w szerszym zakresie, np. ochronie małoletnich przed osobami o skłonnościach pedofilskich. W takich sytuacjach trudno uzależniać stosowanie środka od decyzji pokrzywdzonego w danym postępowaniu.

${ }^{38}$ Wskazywałoby na to opisywane w literaturze psychologiczne zjawisko wyuczonej bezradności, por. L.E. WaLKer: The Battered Woman. New York 1980, s. 42-54.

39 Opinia rzecznik generalnej z dnia 12 maja 2011 r. w poł. spr. Magatte Gueye (C-483/09, Legalis) oraz Magatte Gueye i Valentín Salmerón Sánchez (C-1/10, Legalis), tezy $47-49$. 
W świetle przeprowadzonych ustaleń postulować można jedynie, by sądy orzekały analizowany środek karny każdorazowo po wysłuchaniu pokrzywdzonego z uwzględnieniem jego indywidualnych potrzeb ${ }^{40}$. Wniosek taki wydaje się zgodny nie tylko z założeniami teoretycznymi prezentowanymi w przywoływanej już literaturze, ale też z praktyką niektórych sędziów $^{41}$. Formułując taki postulat, nie można zapominać, że pokrzywdzony czynem z katalogu wynikającego z art. 41a k.k. może być małoletni. W takiej sytuacji nie można, jak sądzę, poprzestać na wysłuchaniu przedstawiciela ustawowego lub wyznaczonego przez sąd kuratora ${ }^{42}$. Konieczne byłoby wysłuchanie samego pokrzywdzonego z zachowaniem zasad obowiązujących w razie przesłuchiwania małoletniego pokrzywdzonego. Ten wątek wymagałby jednak odrębnego opracowania z uwzględnieniem stopnia dojrzałości małoletniego i potrzeby szczególnej ochrony dobra dziecka.

\section{Bibliografia}

\section{Literatura}

Bieńkowska E., Wójcik D.: Pokrzywdzony i sprawca przestępstwa. W: Zagadnienia ogólne. System Prawa Karnego. T. 1. Red. A. Marek. Warszawa 2010.

Falandysz L.: Pokrzywdzony $w$ prawie karnym i wiktymologii. Warszawa 1980.

FILAR M.: Pokrzywdzony (ofiara przestępstwa) $w$ polskim prawie karnym materialnym. CPKiNP 2002, nr 2.

FLeszer D.: Godność i prywatność osoby $w$ świetle Konstytucji Rzeczypospolitej Polskiej. „Roczniki Administracji i Prawa” nr XV(1).

HryNiEWICZ-Lach E.: Ofiara $w$ polskim prawie karnym. Interesy ofiary przestępstwa i karno-materialne instrumenty stużace ich zabezpieczeniu. Warszawa 2017.

JAWORSKA-WIELOCH A.: O potrzebie zachowania spójności wokót nakazu opuszczenia lokalu zajmowanego wspólnie z pokrzywdzonym. W: Współczesne przekształcenia sankcji karnych - zagadnienia teorii, wykładni i praktyki stosowania. Red. P. GóralsKi, A. MuszyńsKa. Warszawa 2018.

Kodeks karny. Część ogólna. T. II: Komentarz do art. 32-116. Red. M. KRóLIKOwsKI, R. ZawŁOCKI. Warszawa 2011.

Kodeks karny. Część ogólna. Komentarz. Red. J. GIEzEK. Warszawa 2012.

KomadowsкA A.: Stosowanie kar i środków karnych wobec sprawców przemocy domowej jako przejaw realizacji funkcji prewencyjnej kary. W: M. Kopeć: Prawnokarna ochrona pokrzywdzonych przemoca domowa. Lublin 2017.

40 Tak też E. Hryniewicz-Lach: Ofiara $w$ polskim prawie karnym..., s. 337.

${ }^{41}$ J. Rumińska, Sędzia Sądu Okręgowego w Katowicach, Wydział VI Karny Odwoławczy, głos w dyskusji na zebraniu Katedry Prawa Karnego i Kryminologii WPiA UŚ w Katowicach, 17.12.2018 r.

${ }^{42}$ Sytuacja jest poniekąd zbliżona do udziału małoletniego w mediacji z dorosłym sprawcą przemocy, por. O. SITARz, D. BeK: Glosa do uchwaty SN z 20 VI 2012, I KZP 9/12. PiP 2014, z. 9, s. 133-139; O. SitARz, D. BeK: Mediacja z udziałem matoletniego. Zagadnienia wiktymologiczne. Arch. Krym. T. XXXVI/2014, s. 363-387. 
Konstytucja RP. T. I: Komentarz do art. 1-86. Red. M. SAfJAN, L. BosEK. Warszawa 2016, Legalis.

Konstytucja Rzeczypospolitej Polskiej. Komentarz. T. 3. Red. L. GarLICKI. Warszawa 2003.

KośLA J.: Zakaz przebywania w określonych środowiskach lub miejscach, kontaktowania się z określonymi osobami, zbliżania się do określonych osób lub opuszczania określonego miejsca pobytu bez zgody sądu. W: Środki karne po nowelizacji $w 2015$ roku. Red. R.A. STEFAŃSKI. Warszawa 2016.

KulESZA C.: Rola pokrzywdzonego $w$ procesie karnym $w$ świetle ustawodawstwa i praktyki krajów zachodnich. Białystok 1995.

KulıK M.: Zakaz przebywania w określonych środowiskach lub miejscach, kontaktowania się z określonymi osobami, zbliżania się do określonych osób lub opuszczania określonego miejsca pobytu bez zgody sądu. W: Środki karne, przepadek $i$ środki kompensacyjne $w$ znowelizowanym Kodeksie karnym. Red. P. DANILUK. Warszawa 2017.

MELEZINI M.: Środki karne jako instrument polityki kryminalnej. Białystok 2013.

MeLEZINI M., SAKOWICZ A.: Zakaz przebywania w określonych środowiskach lub miejscach, kontaktowania się z określonymi osobami, zbliżania się do określonych osób lub opuszczania określonego miejsca pobytu bez zgody sqdu. CPKiNP 2008, nr 2.

MichalsKa-Warias A.: Prawnokarne środki przeciwdziałania przemocy seksualnej między matżonkami $w$ teorii i praktyce. W: M. Kopeć: Prawnokarna ochrona pokrzywdzonych przemocq domowa. Lublin 2017.

NestoRuK I.B.: Wnioskowy tryb ścigania przestępstw $w$ polskim i niemieckim prawie karnym. RPEiS 2001, z. 4.

Osiatý́ski W.: Filozofia $i$ historia praw człowieka. W: Prawa człowieka a policja. Problemy teorii i praktyki. Red. A. RzEPLIŃsKI. Legionowo 1994.

SAKowicz A.: Zakaz przebywania w określonych środowiskach lub miejscach, kontaktowania się z określonymi osobami, zbliżania się do określonych osób lub opuszczania określonego miejsca pobytu bez zgody sądu. W: Kary i inne środki reakcji prawnokarnej. System Prawa Karnego. T. 6. Red. M. MelezinI. Warszawa 2016.

Sitarz O.: Ustawowe znamiona czynu zabronionego: W: Prawo karne. Część ogólna, szczególna i wojskowa. Red. T. DuKIET-NagórsKa. Warszawa 2018.

Sitarz O., BeK D.: Glosa do uchwaty SN z 20 VI 2012, I KZP 9/12. PiP 2014, z. 9.

Sitarz O., BeK D.: Mediacja z udziatem małoletniego. Zagadnienia wiktymologiczne. Arch. Krym. T. XXXVI/2014.

SPUREK S.: Izolacja sprawcy od ofiary. Instrumenty przeciwdziałania przemocy $w$ rodzinie. Warszawa 2013.

SPUREK S.: Ustawa o przeciwdziałaniu przemocy $w$ rodzinie. Praktyczny komentarz. Warszawa 2011.

STEFAŃSKI R.A.: Środek karny $w$ postaci obowiązku powstrzymania się od przebywania $w$ określonych środowiskach lub miejscach, zakazu kontaktowania się z określonymi osobami lub zakazu opuszczania określonego miejsca pobytu bez zgody sadu. PS 2006, nr 6.

WALKer L.E.: The Battered Woman. New York 1980.

ZalewsKi W.: Sprawiedliwość naprawcza. Początek ewolucji polskiego prawa karnego?. Gdańsk 2006. 